\section{Pferdeenzephalitis-Viren, Westamerikanische (WEEV)}

\section{W. Stöcker}

Euroimmun Medizinische Labordiagnostika AG, Lübeck, Deutschland

\section{Englischer Begriff Western equine encephalitis virus}

Beschreibung des Erregers Familie: Togaviridiae; Gattung: Alphavirus; Art: Western equine encephalitis virus. Plusstrang-RNA-Genom, behüllt, 60-70 nm Durchmesser.

Erkrankungen Vorkommen: Westküste der USA und Kanadas sowie in Mexiko, Mittel- und Südamerika; ländliche Gebiete.

Vektoren: Stechmücken (Culex ssp., z. B. Culex tarsalis, u. U. Aedes ssp.).

Wirte: Vögel (Virusreservoir), Pferde, Menschen (Nebenwirte); von Bedeutung sind Epidemien bei Pferden, die Ursprung von Epidemien in menschlichen Populationen sein können.

Klinik: Die westamerikanische Pferdeenzephalitis ähnelt der ostamerikanischen Pferdeenzephalitis, die Infektion verläuft aber in der Regel milder. Bei schweren Verläufen treten u. a. Fieber, Übelkeit, Erbrechen auf; bei etwa $2 \%$ der infizierten Kinder und $0,1 \%$ der infizierten Erwachsenen entwickelt sich eine Enzephalitis (Muskelschwäche/-steife, Reflexverminderung, Nackensteifheit, Spasmen, Sensibilitätsstörungen, Paresen); 3-7 \% Letalität bei Enzephalitis; Rekonvaleszenz kann Jahre dauern, neurologische Folgeschäden sind möglich.

\section{Analytik}

Direktnachweis: Nachweis viraler RNA durch RT-PCR (Polymerase-Kettenreaktion), Virusanzucht.

Serologie: Nachweis spezifischer Antikörper ( $\operatorname{IgM}, \operatorname{IgG}$ ) im Serum oder Liquor durch indirekte Immunfluoreszenz, $\checkmark$ Enzyme-linked Immunosorbent Assay oder $>$ Neutralisationstest.

\section{Probenmaterial}

Direktnachweis: Blut und Blutbestandteile, Gewebe oder Liquor. Das Material sollte bis zur Weiterverarbeitung bei +4 bis $+8{ }^{\circ} \mathrm{C}$ aufbewahrt werden.

Serologie: Serum oder Plasma für den Nachweis der Antikörper sind bei $+4{ }^{\circ} \mathrm{C}$ bis zu 2 Wochen lang beständig, bei $-20{ }^{\circ} \mathrm{C}$ über Monate und Jahre hinweg. Zur Tiefkühlkonservierung des IgM kann man den Proben 80 \% gepuffertes Glyzerin beifügen.

Diagnostische Wertigkeit Der Direktnachweis ist nur während der ersten, akuten Krankheitstage möglich. Spezifische Antikörper (IgG, IgM) findet man nach wenigen Tagen im Serum. Nur ein vierfacher Anstieg des spezifischen Antikörpertiters gilt als eindeutiger Nachweis einer akuten Infektion.

Differenzialdiagnose: Infektionen mit Herpes-Viren, Coxsackie-Viren oder weiteren Arboviren, die das ZNS befallen.

\section{Literatur}

Center for Food Security and Public Health. Iowa State University (2015) Animal disease information. Equine encephalitides. Latest update Jan 2015. Technical factsheet: eastern, western and venezuelan equine encephalomyelitis http://www.cfsph.iastate.edu/Facts heets/pdfs/easter_wester_venezuelan_equine_encephalomyelitis. pdf. Zugegriffen am 11.04.2017

Robert-Koch-Institut, Berlin (2011) Steckbriefe seltener und importierter Infektionskrankheiten. Robert-Koch-Institut, Berlin 